\title{
Developing Kia Tene/Off the Cuff - A resource for field educators in social work in Aotearoa New Zealand
}

Jude Douglas

Jude Douglas is the Fieldwork Coordinator at Nelson Marlborough Institute of Technology in Nelson. In her seven-year experience of coordinating the Fieldwork papers at her institution she has explored various ways to increase the resourcing and support to Field Educators. Jude Douglas can be contacted at Jude.Douglas@nmit.ac.nz.

\section{Abstract}

Kia Tene denotes something to hand, something easily picked up and used. It is the name for a resource set of 14 learning and teaching activities designed specifically for field educators working with social work students in the field in Aotearoa New Zealand. It is available for viewing and use under the Creative Commons 3.0 share-alike licence at http: / / akoaotearoa. ac.nz/ kia-tene.

The Kia Tene/Off the Cuff resource was completed during 2009 and 2010 and funded by Ako Aotearoa National Centre of Tertiary Teaching Excellence. The project was a collaboration between 12 schools of social work led by Jude Douglas. Students, field educators and fieldwork coordinators were involved with its development.

This paper outlines the context of field education in social work education in Aotearoa New Zealand and then describes some key challenges and how this project serves as a response to them.

\section{Field education in Aotearoa New Zealand}

The centrality of fieldwork, the 'heart' of social work education, to learning in social work education is now well established (Kadushin, 1992; Caspi \& Reid, 2002; Clapton \& Cree, 2004; Beddoe \& Maidment, 2009).

Fieldwork experience comprises a significant amount, approaching a half, of teaching and learning time (at least 120 days) on social work courses but attracts significantly less resourcing than the classroom-based learning component. It has proved difficult to identify the proportion of resource dedicated to Field Education as a proportion of overall course budgets. However, it is clearly under-represented when staff, supervision and travel budgets are taken into account.

In addition to being comparatively under-resourced, fieldwork is more complex than class teaching because it involves collaboration between several parties: the student, the agency, 
the field educator, the training institution and, of course, the service user (client); thus what constitutes good practice in teaching and learning has to be carefully negotiated.

In a literature review of practice learning in professional disciplines, Dick, Headrick and Scott (2002) comment that 'in all the literature on social work education... the practice placement is still considered the key element to successfully teaching social work professionals' (p.35).

\section{The programmes}

Social work education in Aotearoa New Zealand is offered by a range of tertiary provider institutions: universities and polytechnics, wānanga and private training organisations. All providers are aware of the implications of the course being recognised (or not) by the Social Work Registration Board (SWRB). Currently the SWRB recognises 15 courses. Of these, two are wānanga-based courses, five are university courses and the remainder are offered by institutes of technology. All are at Bachelor level or above as this has been, since the introduction of voluntary state registration of social workers in 2003, the baseline qualification for graduates to be able to register as social workers. Some are three-year and others are four-year programmes. Processes for monitoring programmes vary, depending on the type of institution.

\section{Calls for consistency}

The strengthening of voices within Aotearoa New Zealand for greater consistency of approach to teaching and learning in fieldwork has increased as the implications of the requirements of registration permeate the existing workforce and inform the responses of schools of social work. In their 2009 paper, Hay and O'Donoghue compared 10 existing programmes and noted that 'learning outcomes, assessment requirements and placement standards vary significantly' (Hay \& O’Donoghue, 2009, p.42).

Their proposal for the development of national standards in field education would seek to 'strengthen current field education programmes, to create a pathway for provisional registration with the Social Workers' Registration Board (SWRB) and to increase clarity for employers in both domestic and overseas markets.' (Hay \& O’Donoghue, 2009, p.42). The development, by the SWRB, of a Practicum policy and of standards of practice with Māori and different ethnic and cultural groups means that many schools are in the process of reviewing their curriculum in order to evidence that these requirements are met for the purposes of programme recognition.

\section{Technology}

The use of online materials, discussion forums and flexible learning approaches has grown rapidly over the last decade (Birkenmaier, 2005; Reisch \& Jarman-Rohde, 2000) and schools of social work are increasingly using technology-based modes to support students. In addition, the development of online toolkits, resources and readings which are freely available through open source software and common licensing arrangements, particularly between educators, has enormous potential in the sense that such material is now available for global scrutiny and use. However currently, there is no uniquely Aotearoa New Zealand material for social work field educators available in this format.

An evaluation of the use of an online forum to support field educators in Nelson (Douglas, 2006) showed that there were still significant barriers to the usefulness of such initiatives, 
the most important being the lack of appropriate technology in workplaces and the time needed to learn about an unfamiliar mode for it to be useful. In the last five years, however, there has been a significant increase in the use of intranet and online training packages by social service providers, particularly in the statutory sector. In addition, the widespread and exponential increase in the private use of the worldwide web and social networking sites has resulted in many more workers becoming familiar and confident users of these modes.

Thus, the fieldwork component in social work education is central, under-resourced, variable and potentially able to make use of a growing amount of overseas and locally generated online resource material to support the learning of field educators and their students.

\section{About Field Educators (Note - appendix 1)}

If the placement is considered the key element to teaching social work professionals, (Dick et al., 2002) then, by implication, the Field Educator is the students' most important teacher. Educators are the agency-based practitioners who work alongside students, most often during block placements of between nine and 15 weeks. They are not always experienced and qualified social workers and few have backgrounds in education. Some of these busy practitioners volunteer for the role, others are co-opted. The role of the tertiary provider is to train and support practitioners to enable them to be the best 'educators' possible within these constraints. This is a tall order.

The literature on the resourcing and support needs of the field educator group is minimal. The experience of field educators collated from five years of evaluation material collated in the Nelson area suggests that field educators:

- Need and want resources to support their work with students;

- Cannot easily get away from their offices to attend institution-based training and support;

- Cannot necessarily access or make good use of web-based resource sets or discussion forums;

- Want resources which are adaptable, easy to use and target certain areas of student learning (Douglas, 2008).

In comparable settings (England, Scotland) practitioners who take on field educator roles in social work education are not only usually trained, experienced and senior practitioners but increasingly have a specific postgraduate qualification in field education, the Practice Teachers' Award.

There are clear reasons then, for reviewing the training and support offered to field educators in Aotearoa New Zealand.

\section{Challenges for field education in Aotearoa New Zealand}

These fall into two main groups - the structural position of social work education in the tertiary sector and of fieldwork within it and changes in thinking about how adults learn.

\section{Position of social work}

The first challenge is the position of the social work profession itself, particularly as it relates to other comparable disciplines in terms of resourcing the education of its emerging workforce. 
The current political climate of 'considerable economic restraint' contributing to a 'potent mix of rather adverse conditions under which students endeavour to make their initial forays into the field of practice' (Maidment, 2006, p.48) increases the tension experienced by all parties. Starting in the 1980s, one factor exerted particular pressure on staff time. This was the increased competition between what were traditionally public services of health, education and welfare and the contingent focus on accountability via the collection of evidence towards 'outputs.'

Beddoe (2007) juxtaposes the competing tensions of the local and global, the risk-led managerial with strengths and value-based ethical approaches and states that educators 'struggle in these spaces.' (p.47). Beddoe also notes the historic lack of an academic research culture in social work and adds that 'most importantly we need to reflect on our approaches to teaching and learning in social work education' and to expand and 'deeper articulate our conscious shift from social work practice to social work pedagogy' $(2007$, p.53). She concurs with others (Hay \& O'Donoghue, 2009) that the way forward in this environment is by collaboration between schools and practitioners.

\section{Position of fieldwork in social work}

The second challenge relates to the position of fieldwork within social work and stems from a structural and long-standing imbalance between value accorded to learning which happens in the classroom compared to the learning which happens in the field.

'Within the university system, field education has cottage industry status, little power or acknowledgement,and its staff are seen as the university's domestic labour' (Cooper, 2007, p.101). Other writers, too, have challenged the discourse in academia where fieldwork, with its emphasis on doing has less status and credibility than thinking or theory as taught in the classroom and lecture theatre (Clapton and Cree, 2004; Bruce and Lishman, 2004; Cooper, 2007).

The SWRB has set standards for policies on the criteria for placements, namely that students:

- undertake a minimum of 120 days of supervised practicum;

- do a minimum of two practica

- do one practicum for at least 50 days

- do at least two practica in different organisational settings

- be exposed to at least two different fields of practice

(Social Workers' Registration Board, 2009)

However, schools' interpretation of these varies. The lack of national consistency of learning outcomes for placements in social work programmes (Hay \& O'Donoghue, 2009) means that there is some confusion about what constitutes good learning and teaching in the field.

Although the last 10 years in particular have seen an increase in the amount of writing about fieldwork in Aotearoa New Zealand, it remains underrepresented in the literature about social work education in general. Several journal articles, two research studies (Ellis, 1998; Maidment, 2000) and several texts, two Australasian (Cooper \& Briggs, 2000; Beddoe \& Maidment, 2009) and one Australian (Cleak \& Wilson, 2004) have dealt with various themes 
while expressing agreement that there is a need to continue to explore and document some aspects of fieldwork in more detail.

The challenges to maintaining quality fieldwork experiences are well documented here in Aotearoa New Zealand as they are in other comparable contexts (Maidment, 2000; Cooper, 2007; Doel \& Shardlow, 1998). They include the lack of trained and qualified practitioners who are able to act as field educators, high staff turnover and the increasing pressure on agency and therefore workers' workloads. Social work programmes in the tertiary sector do not attract the enhanced funding of other programmes with a significant clinical element, for example nursing or teaching.

Consequently, fieldwork 'happens' because of the goodwill of agencies who offer places to students. Staff in liaison and coordination roles in the institutions are very well aware of the need to nurture and support those relationships and often feel some discomfort in insisting that high standards of teaching and learning are adhered to if this might threaten the goodwill of the agency or personnel in the future. The fact that most field educators receive no extra time allowance or reduction in caseload for the duration of the placement adds to the difficulty of fieldwork coordinators insisting that more time is spent on initial training or that additional learning sessions are structured through the placement time. Some field educators, though not all, are able to access supervision and support for their field educator role from within the agency, but for many there is no available expertise or capacity in the agency to support this. Thus, field educators are reliant on contact with busy fieldwork coordinators for support and advice and sometimes experience delays in accessing this. (Douglas, 2008).

A 2008 document prepared by the stakeholder working group for the Tertiary Education Committee (TEC) stated that:

Fieldwork is a key pressure point for all programmes and needs to be creatively and immediately attended to. In saying this it is important as a principle to maintain, within the national standards, regional, sector and culturally appropriate diversity in models for the delivery of fieldwork (Kane, and Briggs, 2008).

This group summarised its findings with a clear message that collaborative approaches must be the mechanism for future development of social work education. In identifying the shifts that needed to occur, it was noted that:

New models of educational delivery for practice-based learning will be in place with all TEOs and agencies contributing to 'regional hubs' and that 'Incentives, investment and resources will support collaboration at all levels' (ANZASWE, 2008).

Beddoe (2007) notes that the relatively large number of smaller schools of social work in Aotearoa New Zealand leave us particularly vulnerable to the challenges of providing quality fieldwork experiences and she too suggests that the way forward is via 'collaboration, mutual support and the development of new partnerships that transcend the competitive

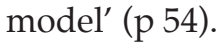

Hay's recent (2011) analysis of an example of cross-institutional collaboration concludes though that 'while there is potential for cross-institutional collaboration in the domain of 
cooperative education, this is, in a large degree, restricted by the current competitive institutional environment' (p.37).

\section{From 'preaching to teaching'}

The second type of challenge identified, is the now well-documented move from 'preaching to teaching' (Beddoe, 1999) and the need for field educators to have a much more acutely developed sense of themselves as adult educators.

Maidment's (2000) survey of 130 field educators and 80 students of their experiences of teaching and learning on placement showed that while both students and field educators were in agreement about which strategies were most likely to facilitate learning in the field, most of these 'were not used to any great extent in placement' and that some students' experiences were 'fairly haphazard and limited' (Maidment, 2000, p.37).

She suggests that one strategy for supporting Field Educators would be to provide access to on-going training, but notes however, that 'workload pressure militated against educators availing themselves of these opportunities' and goes on to state that current practice for training Field Educators is not productive (Maidment, 2000, p.5).

Ideas about adult learning in general, and constructivist approaches in particular, have now been well integrated into tertiary sector classrooms and some common understandings about excellence in teaching and learning about social work in the classroom have developed.

If field education is to have as robust a pedagogical base as classroom learning, the move from Field Educator as practitioner to practice teacher is imperative. More recently, calls for another look at possibilities of making the field experience central to the learning have been made. There are 'strong arguments to maximising what is already available in the workplace (everyday experiences) and augmenting these experiences with a set of structured learning activities' (Billet, 2001 cited in Cooper, 2007, p.102). The work of Cree (2006) which questioned the concept of practice and theory as separate entities is supported by other writers who suggest the way forward is to use increasingly varied models of 'educational supervision with learning as a major focus, more structured learning experiences and greater use of collaborative learning groups' (Cooper, 2007, p.104). Schon's (1987) ideas about the need for professionals to reflect both 'on' and 'in' action since each new situation is likely to have unique features, have been developed by other scholars and lead to a point where each social work encounter has a potential to generate a new, or add to an existing, theory base. The idea that learning must begin in 'the real world' (Cree, 2006, p.13) and an education model which uses critical reflection processes to create knowledge and meaning contribute to a pedagogy which holds examined practice experience central to learning in social work.

In their 2009 text, Beddoe and Maidment acknowledge that 'both social work students and their field educators are having to address increasingly complex case and community concerns' and that the need is for 'reflexive and responsive practitioners' (p.1) Their response has been to organise their text, designed for students and field educators, and including case material from both Aotearoa New Zealand and Australia, into eight curriculum areas which are intersected by four major areas of current critical debate, to facilitate the integration of learning. 


\section{Response to the challenge}

Bogo and Globerman (1995) identify four factors which contribute to the success of placement partnerships, one of which is the provision of resources for the programme. A national survey of field education in Aotearoa New Zealand in 2006 which included the voices of both students and field educators found that 'a lack of resources for field educators within agencies was noted by a significant proportion of respondents' but also that 'we are unclear what these resources are considered to be' (Hay, O’Donoghue \& Blagdon, 2006, p.27). While over $85 \%$ of respondents from each group agreed that well-trained field educators contribute to the aims of field education being achieved, a lack of resources and a lack of training for field educators were the two most significant items identified as contributing to the aims of field education not being achieved. The other, and highest scoring item, was that field educators do not get released from core duties, but this is something which institutions currently have little, if any, control over.

Thus, targeting the improvement in training and resourcing of field educators is an obvious and sensible starting place if we are serious about improving the quality of teaching and learning in the fieldwork component of a social work programme. Another finding of Hay et al's (2006) recent overview was that the area of providing competency to work with Māori was one of two which was highlighted 'as not being well met'. Learning how to work with Māori is a core component of all tertiary programmes and documentation of evidence of its achievement a mandatory requirement for social work registration (Social Workers Registration Board, 2010).

There is clear evidence then that we need to provide better resources for field educators, but there are real challenges around how best to deliver this from an institutional base. Alongside this, there is a tension for students moving from classroom-based learning to the field and a need for better integration of material between classroom and field to enhance learning.

The development of a set of readily accessible, easy to use, adaptable resources, generated from and tailored for use in Aotearoa New Zealand and initially available in both hard copy and electronic forms seemed to be a useful adjunct to the resources for the fieldwork component of social work education.

\section{The Kia Tene/Off the Cuff resource set}

\section{Developing the resource}

The initial concept for the development of the resource was that from the outset the project had input from the field and from the academic institution as well as from Māori and tau iwi. Scoping discussions were initiated, a project plan drawn up and a decision made to apply for funding through the southern regional hub of Ako Aotearoa. The original team of an experienced Māori field educator and a tau iwi fieldwork coordinator began to work on the project, however, the project plan changed after the Mãori worker withdrew for reasons of ill health. This was a crunch point in the project and various possibilities were considered before a decision was made that the tau iwi worker, the writer, would continue with the work of developing the resources with increased consultative input from Māori practitioners. The collaboration of other fieldwork coordina- 
tors was requested and an online forum set up using the Ako Aotearoa site as a host. Students and field educators in Nelson in 2009 were involved in trialling the material in the field. Printed versions of the resource were supplied to 12 schools of social work with a request for other Fieldwork Coordinators to trial and evaluate the material with their groups of field educators. This latter exercise had a disappointing response rate although useful feedback came from the Nelson student group and from the Nelson field educator group. Comment was also sought and obtained from a small group of external supervisors in Nelson and also from the members of the national subcommittee of fieldwork coordinators affiliated to the Council of Social Work Educators of Aotearoa New Zealand (CSWEANZ).

Material was for the most part adapted or reworked from the work of Mark Doel and Steven Shardlow (UK), Helen Cleak and Jill Wilson (Australia) and Liz Beddoe and Jane Maidment (Aotearoa New Zealand), all of whom were very generous in allowing the adaption of their original material. The selection of themes was informed by the ANZASW practice standards and the SWRB competencies and in consultation with schools. Changes were made in response to feedback and a designer was engaged to ensure that the resource 'worked' on the page.

The resource set was posted on the Ako Aotearoa website as a resource in PDF format in July 2011 and is thus searchable and downloadable. It is published under the Creative Commons 3.0 New Zealand Attribution Non-commercial Share Alike Licence. Under this licence work can be copied, distributed, displayed and performed as well as remixed, tweaked or built upon as long as the authors are credited and the new creations licensed under identical terms.

The email group list of CSWEANZ Fieldwork subcommittee membership as well as the Ako Aotearoa online community of Fieldwork Coordinators have continued to be mechanisms for distribution and discussion. At this point in its early life several fieldwork coordinators have indicated that they plan to provide the web link to their group of field educators and encourage them to make use of the resource. Interest has also been shown by professionals in the allied disciplines of nursing and occupational therapy.

\section{Potential uses}

Alongside the obvious usefulness of this resource for field educators, it may have additional uses for staff training and development within the agency itself. Again, this strengthens the expert role of those who become field educators within the agency and may lead to further opportunities for them to be lead workers in creating a learning culture in their own organisation. The overt expectation that field educators are practitioner teachers also challenges the implicit power assumptions between the traditional modes of 'thinking' (the classroom) and 'doing' (the field) where the learning in the classroom has had higher status and rewards despite students reporting the value of their experiences in the field.

The provision of such resources by academic institutions serves to help with the integration of class and field as well as support the development of field educators. The adaption, use and evaluation of such material also immediately engages the field educator in the business of co-constructing learning around how best to work with students and opens up possibilities of shared collegial relationships between the classroom and field. 
Social work is listed as a preferred occupation on the New Zealand Immigration Service's Long Term Skills Shortage list after workforce studies predicted an on-going shortage of graduates (Immigration New Zealand, 2011). Recruitment and retention of students, particularly those from minority groups, remains an issue. Positive experiences in the field are likely to assist retention and completion rates and, most importantly, optimise the learning opportunities for students as beginning practitioners.

\section{Conclusion}

Kia Tene/Off the Cuff is a response to a particular set of circumstances; an identified need for resources which are local, useful and pedagogically sound. It is hoped that the initial set of 14 activities can be grown and developed to respond to the changing needs of the profession.

The amount of online resources available to schools of social work to support student learning in both classroom and field is rapidly growing. Currently this material is situated over many sites and although there are some useful collections, the business of locating, selecting and adapting material for use in our context remains time consuming.

Despite our unique position in being able to access a wealth of knowledge of Māori helping traditions, this is not well represented in the small amount of literature and resource material which does exist. The question of how to support the greater inclusion of indigenous perspectives in both the curriculum and the literature is compelling.

The literature on social work in general and social work education in particular remains dominated by Western discourses: the material which has 'made it online' continues this theme. If Aotearoa New Zealand is to have a voice in this global classroom we must act to begin to generate, document and distribute our unique contribution.

\section{References}

Ako Aotearoa National Centre of Tertiary Teaching Excellence. (2011). Homepage. Retrieved May 30, 2011 from http: / / akoaotearoa.ac.nz.

Aotearoa New Zealand Social Work Educators. (2008). Stakeholder working group report to the Tertiary Education Commission (unpublished).

Beddoe, L. (1999). From preaching to teaching? Changes in field education in Aotearoa New Zealand. Social Work Review, IX, 21-27.

Beddoe, L. (2007). Change, complexity and challenge in social work education in Aotearoa New Zealand. Australian Social Work, 60(1), 46-55.

Beddoe, L., \& Maidment, J. (2009). Mapping knowledge for social work practice: Critical intersections. Melbourne, VIC, Australia: Cengage.

Billet, S. (2001). Learning in the workplace: Strategies for effective practice. Sydney, NSW, Australia: Allen and Unwin.

Birkenmaier, J. (2005). Weaving a web: The use of internet technology in field education. Journal of Teaching and Learning in Social Work, 25(1-2), 3-20.

Bogo, M., \& Globerman, J. (1995). Creating effective university field partnerships: An analysis of two inter-organisational models. Journal of Teaching in Social Work, 11(1/2), 177-92.

Bruce, L., \& Lishman, J. (2004). Learning for effective and ethical practice: Agency based learning. Dundee, Scotland: Scottish Institute for Excellence in Social Work Education.

Caspi, J., \& Reid, W. J. (2002). Educational supervision in social work: A task centered model for field instruction and supervision. New York, NY: Columbia University Press.

Clapton, G., \& Cree, V. (2004). Learning for effective and ethical practice: Integration of learning for practice. Dundee, Scotland: Scottish Institute for Excellence in Social Work Education. 
Cleak, H., Hawkins, L., \& Hess, L. (2000). Innovative field options. In Cooper, L. \& Briggs, L. (Eds.), Fieldwork in the human services. (pp.160-174). Adelaide, SA, Australia: Allen and Unwin.

Cleak, H., \& Wilson, J. (2004). Making the most of field placement. Southbank, Melbourne, VIC, Australia: Thomson.

Cooper, L. (2000). Teaching and learning in human services fieldwork. In Cooper, L. \& Briggs, L. (Eds.). Fieldwork in the Human Services (pp. 3-10). St Leonards, NSW, Australia: Allen and Unwin.

Cooper, L. (2007). Backing Australia's future: Teaching and learning in social work. Australian Social Work, 60,(1),94106.

Cooper, L., \& Briggs, L. (Eds.). (2000). Fieldwork in the human services. St Leonards, NSW, Australia: Allen and Unwin.

Cooper, L., \& Orrell, J. (1999). The practicum: The domestic work of university teaching. HERDSA News, 21(2), 6-9.

Connolly, M., \& Harms, L. (Eds.). (2009). Social work contexts and practice (2nd ed.). Melbourne, VIC, Australia: Oxford University Press.

Cree, V. (January 2006). Integration of learning. Keynote presentation at Practical Experiences in Professional Education Conference, Auckland, New Zealand.

Cree, V. E., \& Macaulay, C. (Eds.). (2000). Transfer of learning in professional and vocational education. London, England: Routledge.

Dick, E., Headrick, D., \& Scott, M. (2002) Practice learning for professional skills: A review of the literature. Edinburgh, Scotland: Scottish Executive.

Doel, M., \& Shardlow, S. (1998). The new social work practice: Exercises and activities for developing social workers. Aldershot, England: Ashgate.

Doel, M., Shardlow, S., Sawdon, C., \& Sawdon, D. (1996). Teaching social work practice: A programme of exercises and activities towards the practice teaching award. Aldershot, England: Ashgate.

Douglas, J. (November 2006). When social workers can't talk... Conference paper (unpublished). Paper presented to ANZASW conference, Palmerston North.

Douglas, J. (2008). What do field educators really want? Evaluation paper in progress (unpublished).

Douglas, J. (2011). Kia Tene/Off the Cuff: Resources for field educators and social work students. Retrieved on July 30, 2011 from http: / / akoaotearoa.ac.nz/ kia-tene.

Ellis, G. (1998). Through the looking glass: fFeldwork supervisors' perceptions of their role and needs for support, education and training. Unpublished Masters thesis. Massey University, Palmerston North, New Zealand.

Hay, K. (2011). Can collaboration co-exist? Building a cross-institutional community of practice. Asia-Pacific Journal of Cooperative Education, 12(1), 31-38.

Hay, K., O'Donoghue, K., \& Blagdon, J. (2006). Exploring the aims of social work field education in the registration environment. Social Work Review, XVIII(4), 20-28.

Hay, K., \& O’Donoghue, K. (2009) Assessing social work field education: Towards standardising fieldwork assessment in New Zealand. Social Work Education, 28(1), 42-53.

Immigration New Zealand. (2011). Retrieved April, 15, 2011 from http:/ / www.immigration.govt.nz/migrant/ stream/work/skilledmigrant/.

International Federation of Social Work Schools. (2011). Global standards document. Retrieved May 5, 2011 from http: / / www.ifsw.org/f38000222.html.

Kane, R., \& Briggs, L. (2008). Report to the Tertiary Education Commission (unpublished). Stakeholder working group report.

Kadushin, A. (1992). Supervision in social work (3rd ed.). New York, NY: Columbia University Press.

Kolb, D. A. (1984). Experiential learning: Experience as the source of learning and development. Upper Saddle River, NJ: Prentice Hall.

Maidment, J. (1997). Enhancing field education for social work students on placement: Tools, methods and processes. Social Work Review, IX(1\&2), 39-43.

Maidment, J. (2000). Methods used to teach social work students in the field: A research report from New Zealand. Social Work Education, 0(0), pp. 145-154. UK: Carfax Publishing.

Maidment, J. (2002). Understanding the theory of practice teaching. Social Work Review, X1V(1), 36-42.

Maidment, J. (2003). Problems experienced by students on field placement: Using research findings to inform curriculum design and content. Australian Social Work, 56(1), 50-60.

Maidment, J. ( 2003). Developing trends in social work field education. Women in Welfare Education Journal, 6, 112.

Maidment, J. (2006). Using on-line delivery to support students during practicum placements. Australian Social Work, 59(1), 47-55.

Reisch, M., \& Jarman-Rohde, L. (2000). The future of social work in the United States: The implications for field education. Journal of Social Work Education, 36(2), 201-14.

Schon, D. A. (1987). Educating the reflective practitioner: Towards a new design for teaching and learning in the professions. San Francisco: Jossey Bass.

Shardlow, S,. \& Doel, M. (1996). Practice learning and teaching. Basingstoke: Macmillan.

Shardlow, S. M., \& Doel, M. (Eds.). (2002). Learning to practise social work: International Approaches. London: Jessica Kingsley. 
Social Workers' Registration Board. (2004). Entitlement to Registration Competence. Social Workers Registration Board, Wellington, New Zealand: Author. 1-7.

Social Workers Registration Board. (2009). Policy statements. Retrieved 25 April, 2011 from http: / / www.swrb.govt. nz/files / Policies / Practicum_SWqualification_February 2011.pdf.

Social Workers Registration Board. (2010). Policy statement. Competence to work with Maori. Retrieved September 21, 2011 from http: / / www.swrb.govt.nz / files / Policies / Competence $\% 20$ to $\% 20$ practise $\% 20$ Social $\% 20$ work $\%$ 20with\%20Maori\%2013_5_2011.pdf.

Supervision in Social Work Field Education Project. (2011). Retrieved May, 2, 2011 from http: / / www.socialworksupervision.csu.edu.au/resources/docs/CSU-guide-social-work-field-education.pdf.

\section{Appendix one: A note on terminology.}

The terms practice, practicum, placement and fieldwork or field instruction or variations on these are used variously in the literature as are the terms Field Instructor, Practice Teacher Field Educator or Placement or Student Supervisor to denote the person responsible for mentoring the student within the agency. The academic institution's representative may be known as the Field Liaison, Placement or Fieldwork Coordinator. I have chosen to use the terms Fieldwork to describe the time the student is on placement in an agency, Field Educator to denote the agency based person responsible for facilitating student learning within the agency and Fieldwork Coordinator to represent the person who is the main liaison point of the institution. These terms are commonly used and understood in Aotearoa New Zealand.

\section{Glossary}

$\begin{array}{ll}\text { ANZASW } & \text { Aotearoa New Zealand Association of Social Workers } \\ \text { CSWEANZ } & \text { Council of Social Work Educators of Aotearoa New Zealand. } \\ \text { IASSW } & \text { The International Association of Schools of Social Work } \\ \text { IFSW } & \text { International Federation of Social Workers } \\ \text { ITO } & \text { Industry Training Organisation } \\ \text { ITPNZ } & \text { Institutes of Technology and Polytechnics of New Zealand } \\ \text { SWRB } & \text { Social Work Registration Board } \\ \text { TEC } & \text { Tertiary Education Commission } \\ \text { TEO } & \text { Tertiary Education Organisation } \\ \text { Wānanga Māori } & \text { Tertiary institution with several campuses }\end{array}$

